\title{
Mechanism of Oncogenic Transformation by Rous Sarcoma Virus
}

\author{
II. Effect of Rifampin on Rous Sarcoma Virus Infection
}

\author{
NANCY J. RICHERT ${ }^{1}$ AND PIERO BALDUZZI \\ Louis A. Wehle Virus Research Laboratory, Department of Microbiology, The University of Rochester School of \\ Medicine and Dentistry, Rochester, New York 14620
}

Received for publication 31 March 1971

\begin{abstract}
Rifampin partially inhibits focus formation and virus production in chick embryo fibroblasts infected with Bryan high-titer Rous sarcoma (RAV-1) virus. This inhibition occurs with exposure to rifampin during a critical period between day 1 and day 2 after infection. This suggests that the drug does not affect formation of the provirus or its transcription or translation after the "fixation" step, but it seems to affect one or more events which take place before fixation and activation of virus production.
\end{abstract}

Rifampin inhibits the replication of a few deoxyribonucleic acid (DNA) viruses such as vaccinia, cowpox, and possibly adenovirus, whereas several ribonucleic acid (RNA) viruses are insensitive to this drug (6). Recently, Diggelmann and Weissmann (3) reported that morphological conversion by Rous sarcoma virus (RSV), an oncogenic RNA virus of the avian leukosis groups, is inhibited by rifampin. With this group of viruses, however, the viral information within the cells is thought to be in the form of a DNA provirus $(8,9)$. We recently investigated the role of the provirus in morphological conversion and found that intracellular inactivation of proviral DNA by treatment with 5-bromodeoxyuridine (BUdR) and visible light results in suppression of focus formation by RSV (1). Since it is known that rifampin in bacteria blocks DNA transcription by binding to the DNA-dependent RNA polymerase complex (4), we thought it of interest to investigate whether rifampin inhibits focus formation of RSV by affecting the proviral DNA.

The results of our experiments suggest that rifampin at the dose used here does not affect the virion-associated enzymes involved in the synthesis of proviral DNA recently described by Temin and Mizutani (11) nor does it affect transcription or translation of the provirus after fixation of the transformed state as defined by Temin (9). Rather, the drug inhibits an early event which

\footnotetext{
1 Part of this work has been carried out by N. J. Richert, National Institutes of Health predoctoral trainee, in partial fulfillment of the requirement for a degree of Doctor of Philosophy and was presented at the 69th Annual Meeting of the American Society for Microbiology, Boston, Mass., 26 April-1 May, 1970.
}

takes place in infected cells, presumably after the synthesis of the provirus, and which affects both fixation of the transformed state and activation of virus production.

\section{MATERIALS AND METHODS}

The Bryan high-titer strain of Rous sarcoma virus [B-RSV-(RAV-1)] and chick embryo fibroblasts (CEF) cultures were used as previously described (1). Focusforming unit (FFU) assays and infectious center assays were carried out by established procedures (12). All experiments reported here were carried out with secondary cultures of CEF brought to a stationary phase by the use of Eagle's minimal essential medium (MEM) without serum as already described (1). Rifampin was kindly supplied through the courtesy of F. Nicolis and G. C. Lancini, Lepetit SPA (Milano, Italy).

\section{RESULTS}

Preliminary experiments have indicated that rifampin at concentrations of $100 \mu \mathrm{g} / \mathrm{ml}$ or less in F12 medium with serum (growth medium) does not affect the percentage of cells in DNA synthesis or the rate of cell growth if exposure to the drug is limited to a $24-\mathrm{hr}$ period. However, prolonged exposure to rifampin significantly decreases the rate of cell growth and higher doses of the drug induce morphological alterations of cells (unpublished data).

To study the effect of rifampin on focus formation, second-passage stationary phase cultures of CEF were infected with approximately $100 \mathrm{FFU}$ of virus and fed after adsorption with growth medium containing antiserum against B-RSV- 
(RAV-1) to prevent secondary infections. Different sets of plates were exposed to rifampin during different 24-hr periods starting from day 0 (time of infection) and for several days thereafter. Both rifampin-treated cultures and controls without rifampin were overlaid with agar medium containing no rifampin at the end of the last treatment period.

The results presented in Table 1 indicate that rifampin does not significantly affect the early phase of infection when the synthesis of proviral DNA is known to occur (10). Rather, rifampin seems to inhibit some early event after the formation of the provirus, since the inhibition of focus formation is maximal with exposure to rifampin between 24 and $48 \mathrm{hr}$ after infection (experiments 1 and 2). Moreover, exposure to the drug from day 0 to day 2 does not increase the level of inhibition of focus formation over exposure between day 1 to day 2 (experiment 3 ).

The degree of inhibition obtained in different experiments varied considerably with different embryos. No complete or near complete suppression of focus formation was ever obtained in these conditions, the maximum inhibition observed being usually between 50 and $75 \%$. With some embryos, no significant inhibition could be detected. The reasons for such failure to suppress focus formation are not understood at present.

To determine whether the steps involved in the fixation of the transformed state, namely cell DNA synthesis and cell division (9), were affected by rifampin, experiments were carried out in which stationary cultures were infected and maintained in MEM medium without serum for $24 \mathrm{hr}$ after infection. In these conditions, synthesis of the provirus is known to occur $(1,10)$. The cultures were then exposed to rifampin between day 1 and day 2 postinfection in either growth medium or MEM without serum in the presence of antiserum against RSV. At the end of this 24-hr period, the cultures were overlaid with F12 agar medium, and the foci were counted 8 days later.

The results of these experiments (Table 2) show that inhibition by rifampin occurs also in cultures maintained in stationary phase during the treatment. This suggests that the inhibition does not depend on cellular DNA synthesis and occurs before the fixation step. However, no data are available on the residual effects of rifampin after removal of the drug.

To investigate whether the effect of rifampin on focus formation is paralleled by an inhibition of virus production, the following experiments were performed.

The effect of rifampin on focus formation was determined as before. Similar sets of plates were infected at a multiplicity of about 0.1 to 0.2
TABLE 1. Effect of rifampin on focus formation by Rous sarcoma virus ${ }^{a}$

\begin{tabular}{|c|c|c|c|c|c|c|c|}
\hline \multirow{2}{*}{$\frac{\text { Expt }}{1}$} & \multirow{2}{*}{$\begin{array}{l}\begin{array}{c}\text { Time of } \\
\text { treatment }\end{array} \\
\text { None }\end{array}$} & \multicolumn{4}{|c|}{ Foci per plate } & \multirow{2}{*}{$\begin{array}{r}\text { Avg } \\
73\end{array}$} & \multirow{2}{*}{$\begin{array}{c}\begin{array}{c}\text { Per } \\
\text { cent }\end{array} \\
100\end{array}$} \\
\hline & & 63 & 70 & 78 & 80 & & \\
\hline & Day $0-1$ & 51 & 52 & 61 & 62 & 57 & 78 \\
\hline & Day $1-2$ & 14 & 15 & 20 & 23 & 18 & 25 \\
\hline & Day 2-3 & 43 & 45 & 56 & 50 & 49 & 67 \\
\hline & Day 3-4 & 70 & 80 & 98 & 102 & 88 & 120 \\
\hline \multirow[t]{5}{*}{2} & None & 45 & 49 & 50 & 56 & 50 & 100 \\
\hline & Day $0-1$ & 42 & 43 & 43 & 53 & 45 & 90 \\
\hline & Day 1-2 & 21 & 23 & 24 & 29 & 24 & 48 \\
\hline & Day 2-3 & 46 & 48 & 50 & 53 & 49 & 98 \\
\hline & Day 3-4 & 45 & 49 & 60 & 62 & 54 & 108 \\
\hline \multirow[t]{4}{*}{3} & None & 101 & 110 & 128 & & 113 & 100 \\
\hline & Day 0-1 & 117 & 120 & 135 & & 124 & 110 \\
\hline & Day $1-2$ & 45 & 59 & 64 & & 56 & 50 \\
\hline & Day 0-2 & 43 & 54 & 59 & & 52 & 46 \\
\hline
\end{tabular}

a Stationary cultures of chick embryo fibroblasts were infected with 100 focus-forming units/plate of Bryan high-titer strain of Rous sarcoma (RAV-1) virus and fed with F12 medium with $5 \%$ calf serum. At the time indicated, rifampin at a final concentration of $50 \mu \mathrm{g} / \mathrm{ml}$ (expt 1) and 100 $\mu \mathrm{g} / \mathrm{ml}$ (expt 2 and 3 ) was added to the cultures. Plates were overlaid after the rifampin treatment with F12 agar medium without rifampin.

TABLE 2. Effect of rifampin treatment in medium with and without serum ${ }^{a}$

\begin{tabular}{|c|c|c|c|c|c|c|}
\hline \multirow{2}{*}{$\begin{array}{l}\text { Plate } \\
\text { A }\end{array}$} & \multirow{3}{*}{$\frac{\text { Medium }}{\begin{array}{c}\text { F12+ se- } \\
\text { rum }\end{array}}$} & \multirow{3}{*}{$\begin{array}{l}\text { Rifampin } \\
\text { None } \\
75 \mu \mathrm{g} / \mathrm{ml}\end{array}$} & \multicolumn{2}{|c|}{$\begin{array}{l}\text { Foci per } \\
\text { plate }\end{array}$} & \multirow{2}{*}{$\begin{array}{r}\text { Avg } \\
63\end{array}$} & \multirow{2}{*}{$\begin{array}{c}\begin{array}{c}\text { Per } \\
\text { cent }\end{array} \\
100\end{array}$} \\
\hline & & & 5360 & 75 & & \\
\hline & & & 1618 & 20 & 18 & 29 \\
\hline \multirow[t]{2}{*}{ B } & MEM, no & None & 2120 & 31 & 24 & 100 \\
\hline & serum & $75 \mu \mathrm{g} / \mathrm{ml}$ & 1213 & 15 & 13 & 54 \\
\hline
\end{tabular}

a Stationary cultures were infected with 100 focus-forming units/plate of Bryan high-titer strain of Rous sarcoma (RAV-1) virus per plate and fed with minimal essential medium (MEM) without serum. On day 1 after infection, plates $A$ were fed F12 medium plus $5 \%$ calf serum with or without rifampin. Plates B were fed MEM with or without rifampin. After $24 \mathrm{hr}$, all plates were overlaid with F12 agar medium without rifampin.

FFU/cell and fed with growth medium without antiserum against RSV. After $24 \mathrm{hr}$ of exposure to rifampin between day 1 and day 2, the supernatant fluids were harvested and titrated for infectivity. The cells were then trypsinized, seeded at a density of 500 cells per plate on monolayers of 
TABLE 3. Effect of rifampin on Rous sarcoma virus infection

\begin{tabular}{|c|c|c|c|c|c|c|}
\hline \multirow{2}{*}{ Rifampin } & \multicolumn{2}{|c|}{$\begin{array}{c}\text { Focus } \\
\text { formation }\end{array}$} & \multicolumn{2}{|c|}{$\mathrm{ICA}^{b}$} & \multicolumn{2}{|c|}{ Virus production ${ }^{b}$} \\
\hline & $\begin{array}{l}\text { Foci/ } \\
\text { plate }^{c}\end{array}$ & $\begin{array}{l}\text { Per } \\
\text { cent }\end{array}$ & $\begin{array}{l}\text { Foci/ } \\
\text { plate }\end{array}$ & $\begin{array}{l}\text { Per } \\
\text { cent }\end{array}$ & $\mathrm{FFU} / \mathrm{ml}$ & $\begin{array}{l}\text { Per } \\
\text { cent }\end{array}$ \\
\hline None & 70 & 100 & 68 & 100 & $1.9 \times 10^{5}$ & 100 \\
\hline $75 \mu \mathrm{g} / \mathrm{ml}$ & 39 & 56 & 29 & 43 & $0.9 \times 10^{5}$ & 47 \\
\hline
\end{tabular}

${ }^{a}$ Cultures were treated as in the experiments of Table 1; rifampin was added for $24 \mathrm{hr}$ between day 1 and day 2 after infection.

${ }^{b}$ ICA, infectious center assay. Cultures were treated as above except $3 \times 10^{5}$ focus-forming units (FFU)/plate were used for infection. At the end of the rifampin treatment, samples of supernatant fluids were assayed for infectious virus, and the cells were resuspended and assayed for infectious centers (500 cells/plate).

${ }^{c}$ Average of four plates.

TABLE 4. Effect of rifampin on virus production ${ }^{a}$

\begin{tabular}{c|l|l|r}
\hline $\begin{array}{c}\text { Time of } \\
\text { treatment }\end{array}$ & Rifampin & Titer (FFU/ml) & $\begin{array}{c}\text { Per cent } \\
\text { virus } \\
\text { production }\end{array}$ \\
\cline { 1 - 3 } Day 1-2 & None & $2.4 \times 10^{5}$ & 100 \\
& $75 \mu \mathrm{g} / \mathrm{ml}$ & $6.9 \times 10^{4}$ & 29 \\
Day 2-3 & None & $2.5 \times 10^{5}$ & 100 \\
& $75 \mu \mathrm{g} / \mathrm{ml}$ & $3.7 \times 10^{5}$ & $>100$ \\
Day 4-5 & None & $6.6 \times 10^{5}$ & 100 \\
& $75 \mu \mathrm{g} / \mathrm{ml}$ & $1.5 \times 10^{6}$ & $>100$ \\
\hline
\end{tabular}

a Stationary cultures of chick embryo fibroblasts were infected with $3 \times 10^{5}$ focus-forming units (FFU)/plate and exposed to rifampin at the time indicated. At the end of the rifampin treatment, samples of supernatant fluid were assayed for infectious virus in previously prepared plates of chick embryo fibroblasts.

sensitive cells in the presence of RSV antiserum, and overlaid the next day to assay the number of infectious centers.

The results (Table 3 ) indicate that the suppression of focus formation is paralleled by an inhibition of virus production. Furthermore, the number of virus-producing cells as obtained by the infectious center assay is reduced to the same extent as virus production. This indicates that inhibition of virus production is not due to a decreased production of virus per infected cell but to a reduction in the number of virus-producing cells. In other experiments, exposure to rifampin for $24 \mathrm{hr}$ at day 2 and day 4 after infection did not affect virus production (Table 4).

\section{DISCUSSION}

The findings of Diggelmann and Weismann (3) were confirmed by the present study only in part. The amount of inhibition of focus formation obtained in our system did not approach the values observed by these authors. On the other hand, it was found that the suppression of focus formation was paralleled by inhibition of virus production. The results of our study also indicate that maximum effect on focus formation and virus production by rifampin occurs during a critical period of time between day 1 and day 2 after infection. It was found previously that proviral synthesis in CEF occurs to a large extent during the first $24 \mathrm{hr}$ after infection, as shown by the fact that inhibitors of DNA synthesis are effective in suppressing focus formation only if they are present during the 24 -hr period immediately after infection (10). These findings were also confirmed by experiments of inactivation of focus formation by treatment with BUdR and light $(1,2)$. Since there is little or no focus suppression if cells are treated with rifampin during the first $24 \mathrm{hr}$, it seems that rifampin does not inhibit transcription of viral RNA by the recently described enzymes associated with the virion (11). This is in agreement with the recent finding by Green and co-workers (5) obtained with several RNA tumor viruses.

Rifampin, however, seems to act before the activation of the provirus. It is known that this process requires the synthesis of cellular DNA (9). In our experience, maintenance of cultures in MEM without serum effectively keeps the cells in stationary phase (1). Yet the results shown here indicate that if cell DNA synthesis and division are blocked by starvation, rifampin suppresses focus formation beyond the level of reduction caused by MEM alone.

Treatment with rifampin 2 or more days after infection is not effective in suppressing focus formation or virus production. This suggests that translation of proviral DNA is not affected by the drug after fixation.

The mechanism by which rifampin inhibits morphological conversion and virus production is not clear. Two possibilities can be considered. The first is that some provirus-specific function is affected by the drug. At present, no proviral functions are known to occur before fixation and activation of viral production take place, but such a possibility should be kept in mind in light of the required functioning of the viral genome before integration occurs in $\lambda$ phage (7).

Alternatively, a cell-mediated effect of rifampin which would delay fixation could be considered. 
In either case, a nonintegrated provirus would be expected to decay, according to data by Boettiger (2). However, since rifampin at the concentration used here does not damage the cells, the provirus surviving in a fraction of cells can become fixed after removal of the drug. After fixation has taken place, morphological conversion and virus production are no longer affected by rifampin.

\section{ACKNOWLEDGMENTS}

This investigation was supported by Public Health Service research grant CA-05206 from the National Cancer Institute and graduate training grant GM-00592 from the National Institute of General Medical Sciences.

We are grateful to Barbara Shambo for excellent technical assistance and to J. R. Christensen and H. R. Morgan for helpful discussion.

\section{ADDENDUM IN PROOF}

After completion of this study, H. L. Robinson and W. S. Robinson (J. Nat. Cancer Inst. 46: 785-788, 1971) reported inhibition of focus formation by Rous sarcoma virus-infected cells and of production of infectious virus after prolonged exposure of cultures to rifampin. This treatment also caused inhibition of cell growth and morphological alteration of cells. Although in their experimental conditions the effect of rifampin on cells is likely to be responsible for the inhibition of focus formation, patent cell toxicity does not seem to be the obvious cause for the inhibition of transformation obtained in our experiments in which cells were exposed to rifampin for $24 \mathrm{hr}$.

\section{LITERATURE CITED}

1. Balduzzi, P., and H. R. Morgan. 1970. Mechanism of oncogenic transformation by Rous sarcoma virus. I. Intracellular inactivation of cell-transforming ability of Rous sarcoma virus by 5-bromodeoxyuridine and light. J. Virol. 5:470-477.

2. Boettiger, D., and H. M. Temin. 1970. Light inactivation of focus formation by chicken embryo fibroblasts infected with avian sarcoma virus in the presence of 5-bromodeoxyuridine. Nature (London) 228:622-624.

3. Diggelmann, H., and C. Weissmann. 1969. Rifampicin inhibits focus formation in chick fibroblasts infected with Rous sarcoma virus. Nature (London) 224:1277-1279.

4. DiMauro, E., L. Snyder, P. Marino, A. Lamberti, A. Coppo and G. P. Tocchini-Valentini. 1969. Rifampicin sensitivity of the components of DNA-dependent RNA polymerase Nature (London) 222:533-537.

5. Gurgo, C., R. K. Ray, L. Thiry, and M. Green. 1971. Inhibitors of the RNA and DNA dependent polymerase activities of RNA tumor viruses. Nature New Biol. 229:111114.

6. Subak-Sharpe, J. H., M. C. Timbury, and J. F. Williams. 1969. Rifampicin inhibits the growth of some mammalian viruses. Nature (London) 222:341-345.

7. Signer, E. R. 1969. The integration problem. Annu. Rev. Microbiol. 22:451-488.

8. Temin, H. M. 1964. The participation of DNA in Rous sarcoma virus production. Virology 23:486-494.

9. Temin, H. M. 1967. Studies on carcinogenesis by avian sarcoma viruses. V. Requirement for new DNA synthesis and for cell division. J. Cell. Physiol. 69:53-64.

10. Temin, H. M. 1968. Carcinogenesis by avian sarcoma viruses. Cancer Res. 28:1835-1838.

11. Temin, H. M., and S. Mizutani. 1970. RNA-dependent DNA polymerase in virions of Rous sarcoma virus. Nature (London) 226:1211-1213.

12. Temin, H. M., and H. Rubin. 1958. Characteristics of an assay for Rous sarcoma virus and Rous sarcoma cells in tissue culture. Virology 6:669-688. 